Mem. Inst. Oswaldo Cruz, Rio de Janeiro, Vol. 82, Suppl. Ill: 83-88, 1987

Intern. Symp. on Insects

\title{
VITELLOGENESIS IN MANDUCA SEXTA
}

\author{
JOHN K. KAWOOYA, ELLIE O. OSIR* \& JOHN H. LAW
}

Department of Biochemistry, The University of Arizona, Biosciences West, Tucson, AZ 85721 USA

Eggs of Manduca sexta contain four well-characterized proteins derived from hemolymph: vitellogenin and lipophorin (very high density lipoproteins); microvitellogenin, a 26,000 dalton female-specific protein lacking lipid and carbohydrate, and insecticyanin, a blue biliprotein composed of four identical 22,000 dalton subunits. In addition, eggs contain a large store of triacylglycerols.

It has been shown that vitellogenin and lipophorin are actively taken up by follicles in vitro. The lipid components of these two proteins together account for only $10 \%$ of egg lipid. The follicle actively sequesters intact high density lipophorin, which, inside the oocyte, is stripped of much of its neutral lipid and two molecules of apolipophorin III. On the other hand, low density lipophorin donates diacylglycerol to the oocyte without its protein components being sequestered. Most of the egg lipid is transported from the fat body by a shuttle system involving low density lipophorin.

Production of the insect egg is a complicated process, requiring the collaboration of at least three tissues, fat body, hemolymph, and ovary. At the molecular level, egg production involves hormonal regulation of gene expression, controlled protein synthesis, post-translational modification, transport of proteins and nutrients, endocytosis and exocytosis, and a host of other biochemical events. To summarize all that is known about egg production in various insects would require a major monograph. We will, therefore, limit our summary to the molecular events in one insect, the tobacco hawkmoth, Manduca sexta, which is a popular experimental animal because of its size and ease of culture.

Composition of the Egg - Analysis of the Manduca sexta egg shows that it contains large amounts of proteins and lipids (Table I). Most of these materials arise in the fat body and are transported through the hemolymph to the

TABLE 1

Composition of the Manduca sexta egg

\begin{tabular}{lr}
\hline Diameter & $1.64 \mathrm{~mm}$ \\
Fresh weight & $1565 \mu \mathrm{g}$ \\
Dry weight & $470 \mu_{\mathrm{g}}$ \\
Total buffer soluble Protein & $148 \mu_{\mathrm{g}}$ \\
Buffer insoluble protein & $129 \mu_{\mathrm{g}}$ \\
Total lipids & $183 \mu_{\mathrm{g}}$ \\
Total carbohydrate & $10 \mu \mathrm{g}$ \\
\hline
\end{tabular}

*Present address: International Centre for Insect Physiology and Ecology, P.O. Box 30772, Nairobi, Kenya.

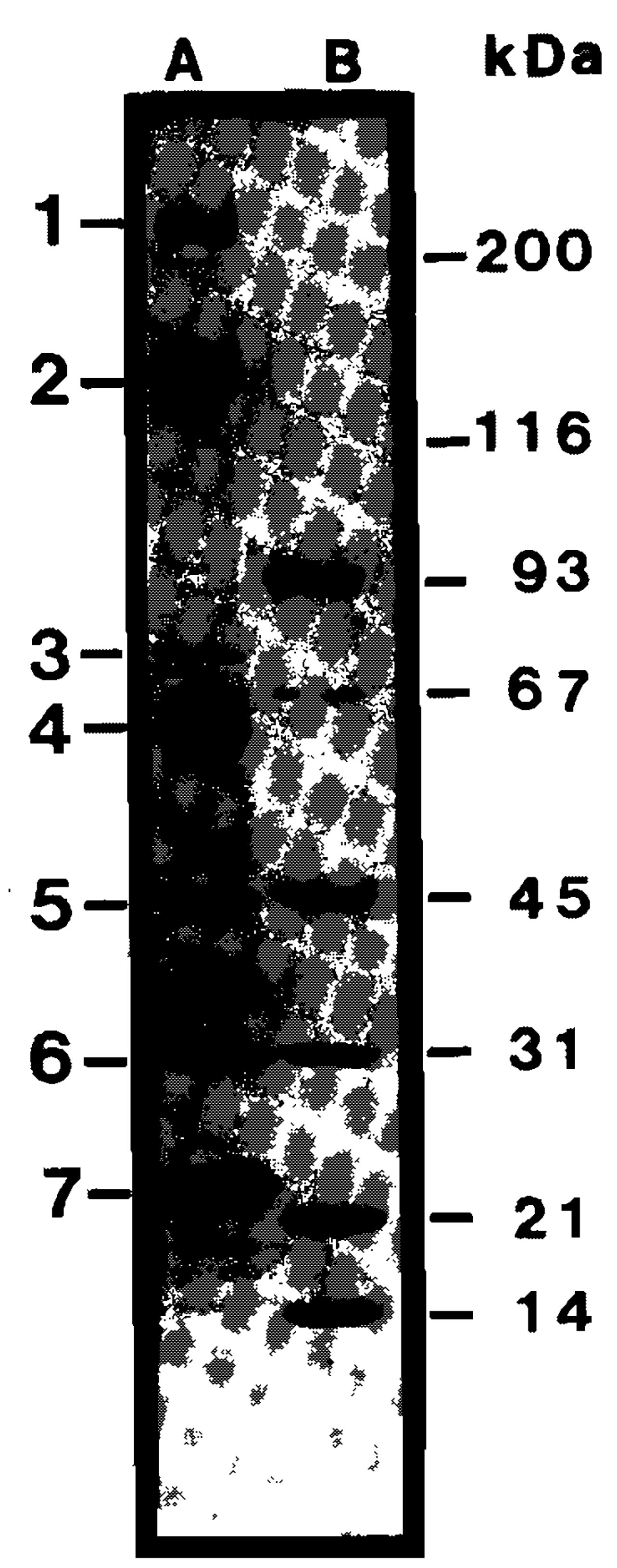

Fig. 1: SDS-poiyacrylamide gel electrophoresis of buffer soluble proteins of Manduca sexta eggs. Lane A: 1 , apoLp-I; 2, apoVg-I; 3, apoLp-I1; 4, eggs specific protein or paravitellin, a product of the follicle cells; 5 , apoVg-II; 6, microvitellogenin; 7, insecticyanin. $\mathrm{B}$ : molecular weight markers. 
TABLE II

Properties of some major Manduca sexta egg proteins

\begin{tabular}{|c|c|c|c|c|}
\hline Protein & $\begin{array}{l}\text { Native } \\
\text { molecular } \\
\text { weight }\end{array}$ & $\begin{array}{l}\text { Subunit } \\
\text { structure }\end{array}$ & Conjugates & Comment \\
\hline Vitellin* & $\sim 500,000$ & $\begin{array}{l}2 \text { Apo Vg-I } \\
2 \text { ApoVg-II }\end{array}$ & $\begin{array}{l}\text { Lipids } \\
\text { Carbohydrate } \\
\text { Phosphate }\end{array}$ & $\begin{array}{l}\text { Major protein } \\
\text { in terms of mass }\end{array}$ \\
\hline Lipophorin ** & 420,000 & $\begin{array}{l}1 \text { ApoLp-I } \\
1 \text { ApoLp-II }\end{array}$ & $\begin{array}{l}\text { Lipids } \\
\text { Carbohydrates }\end{array}$ & $\begin{array}{l}\text { A very high } \\
\text { density } \\
\text { lipoprotein } \\
\text { ( } 80 \% \text { protein. } \\
20 \% \text { lipid) }\end{array}$ \\
\hline Microvitellogenin ${ }^{+}$ & $\sim 26,500$ & $\begin{array}{l}\text { one } \\
\text { polypeptide }\end{array}$ & none & $\begin{array}{l}\text { Sequence has } \\
\text { been } \\
\text { determined }\end{array}$ \\
\hline Insecticyanin ${ }^{++}$ & 88,000 & $\begin{array}{l}4 \text { identical } \\
22,000 \mathrm{MW} \\
\text { subunits }\end{array}$ & $\begin{array}{l}\text { biliverdin } \\
\text { IX }-\gamma\end{array}$ & $\begin{array}{l}\text { Sequence and } \\
\text { crystal } \\
\text { structure have } \\
\text { been determined }\end{array}$ \\
\hline
\end{tabular}

* Osir et al., 1986a.

* Osir \& Law, unpublished.

${ }^{+}$Kawooya et al., 1986

${ }^{+}+$Riley et al., 1984; Holden et al., 1987.

developing egg. When eggs are homogenized and the buffer soluble proteins are subjected to polyacrylamide gel electrophoresis, a few major protein bands and many minor ones can be observed (Fig. 1). Some of these represent true egg components, while others arise from the action of potent proteases that are released during homogenization. Even in the presence of protease inhibitors, one must not assume that all proteolytic action has been halted.

We will discuss four proteins known to be present in the egg. Three of these, vitellin, microvitellogenin and lipophorin, constitute the major buffer soluble egg proteins, while another, insecticyanin, contributes to the green coloration, which presumably serves to camouflage the egg. The characteristics of these proteins are listed in Table II.

Vitellogenin and Vitellin - As in most insects (Kunkel \& Nordin, 1985), the major egg protein of $M$. sexta, vitellin, is derived from a precursor, vitellogenin. Vitellogenin is synthesized by the fat body, secreted into the hemolymph and sequestered by the ovary (Imboden \& Law, 1983; Osir et al., 1986a). Vitellogenin and vitellin are very similar in composition and properties (Mundall \& Law, 1979 ) with only subtle differences between their electrophoretic mobilities (Imboden \& Law, 1983). The molecular differences between these complex molecular aggregates are not fully understood. Each complex is made up of phosphoglycoproteins and a mixture of lipids (Mundall \& Law, 1979; Osir et al., 1986a). The composition of $M$. sexta vitellogenin is summarized in Table III. The protein complement consists of two immu. nologically distinct apoproteins, apoVg-I $\left(M_{\mathrm{r}} \approx 177,000\right)$, and apoVg-II $\left(\mathrm{M}_{\mathrm{r}} \approx 45,000\right)$, and their properties are presented in Table IV.

TABILE III

Composition of Manduca sexta vitellogenin

$\begin{array}{lrr}\text { Proteins } & 84.5 \\ \text { Carbohydrates } & 3.0 \\ \text { Lipids } & & 12.5 \\ & & 7.2 \\ & \text { Phospholipids } & 5.3\end{array}$

Phospholipids

Percent of total lipids

Diacylglycerol

62.6

3.7

Free $\quad 6.9$

4.3

Hydrocarbons $\quad 1.1$ 
TABLE IV

Composition of vitellogenin apoproteins

\begin{tabular}{lcc}
\hline & ApoVg-I & ApoVg-II \\
Molecular weight & 177,000 & 45,000 \\
$\begin{array}{l}\text { Carbohydrate chains } \\
\text { Protein-bound } \\
\text { phosphate residues }\end{array}$ & $3-4$ & 0 \\
$\begin{array}{c}\text { Number per vitellogenin } \\
\text { particle }\end{array}$ & 23 & $\sim 15$ \\
\hline
\end{tabular}

Data from Osir et al., 1986a.

* Mannose 9 NAcGlucosamine ${ }_{2}$, Osir et al., 1986b.

The structural organization of $M$. sexta vitellogenin is similar to that of vitellogenin from several other insect species (Harnish \& White, 1982; Wyatt et al., 1984; Kunkel \& Nordin, 1985). In locusts, several apoproteins of vitellogenin are encoded in two homologous genes, and appear to be derived by proteolytic processing of a single large polypeptide that is translated from a single large mRNA (Harnish et al., 1982; Wyatt et al., 1984). A similar large polypeptide precursor has been found in a cockroach, Leucophaea maderae (Della-Cioppa \& Engelmann, 1987). It would not be surprising if such processing occured during vitellogenin synthesis in $M$. sexta.

In many insects ecdysone and juvenile hormones play a role in the synthesis of vitellogenin by the fat body (Koeppe et al., 1985; Hagedorn, 1985). In $M$. sexta, virtually nothing is known about possible control of vitellogenin synthesis by ecdysteroids, but it is clear that juvenile hormone is not required, because allatectomized animals can synthesize vitello genin (Nijhout \& Riddiford, 1974). Indeed vitellogenin levels in the hemolymph of decapitated animals (which lack corpora allata, and thus are devoid of juvenile hormone) are equal to those of whole animals (Nijhout \& Riddiford, 1974). Nonetheless, decapitated animals are incapable of producing mature eggs. Although vitellogenin appears to be sequestered by the follicles of such animals, the follicles never grow to full size $(1.6 \mathrm{~mm})$. Instead, growth is arrested when the follicles reach approximately $1 \mathrm{~mm}$ in size, after which they are resorbed (Nijhout \& Riddiford, 1974; 1979). This sug. gests that the main effect of juvenile hormone is a gonadotrophic one on the ovary, but gives us no information as to its mode of action.

One effect of juvenile hormone might be the induction of membrane-bound receptors that are required for the sequestration of hemolymph proteins into the oocyte. A search for such membrane receptors has begun.

The sequestration of vitellogenin by $M$. sexta follicles has been demonstrated in vitro (Osir \& Law, 1986). Membrane preparations from homogenized follicle bind isotopically labeled vitellogenin with high affinity and specificity. These results suggest the presence of an endocytotic receptor for vitellogenin in the follicle membranes (Osir \& Law, 1986).

Microvitellogenin or Microvitellin, a New Vitellogenic Protein - Telfer et al. (1981) described a low molecular weight hemolymph and egg protein from Hyalophora cecropia, which they named "reluctin", because of its appearance rather late during egg development. They suggested that "reluctin" was not female-specific, and therefore, not a true vitellogenic protein. Telfer \& Kulakosky (1984) later renamed this protein microvitellin and suggested that it was more prevalent in female hemolymph than in male hemolymph. Simultaneously, we isolated a female-specific hemolymph protein from $M$. sexta with properties very similar to those of the $H$. cecropia protein, but we called it microvitellogenin because it was found in hemolymph (Kawooya \& Law, 1983). Later we showed that microvitellogenin was synthesized by the fat body and was present in the eggs of $M$. sexta (Kawooya et al., 1986).

In $M$. sexta. microvitellogenin is produced only in the females. No mRNA for this protein can be detected in the male fat body by north. em blotting techniques (X. -Y. Wang, K. D. Cole \& J. H. Law, unpublished). Microvitellogenin is accumulated in the eggs, where it accounts for 6 percent by weight of the buffer soluble egg proteins. On a molar basis, the amount of microvitellogenin is equal to that of vitellogenin in the egg (Kawooya et al., 1986). Microvitellogenin appears in the hemolymph approximately 18 days before adult emergence. Decapitation of $M$. sexta pupae 6 days prior to adult emergence does not seem to prevent further microvitellogenin synthesis. While less of the protein occurs in the immature eggs of these animals, this is probably a secondary consequence of the failure of follicles to grow beyond $1 \mathrm{~mm}$ in size (Kawooya \& Law, 1983).

Kulakosky \& Telfer (1984) have reported the in vitro uptake of microvitellogenin by $H$. cecropia follicles. We have so far not succeeded 
in demonstrating microvitellogenin uptake by $M$. sexta follicles in vitro; however, when labeled microvitellogenin is injected in to the hemolymph of adult female $M$. sexta, it is rapidly sequestered by the follicles (N. S. Bartfeld, J.K. Kawaooya \& J. H. Law, unpublished). Microvitellogenin does not compete with vitellogenin for binding to follicle membranes. Therefore, these two proteins may be internalized on separate receptor systems (Osir \& Law, 1986).

Lipophorin, the principal lipoprotein of insect hemolymph (Chino et al., 1981), is also a major component of the insect egg (Chino et al., 1977; Telfer et al., 1981). Chino et al. (1977) showed that unlike hemolymph lipophorin, the lipophorin from the eggs of Philosomia cynthia was lipid depleted. They postulated that hemolymph lipophorin served to deliver lipids to the ovary by entering the oocyte, depositing its lipids, and exiting again, to be reloaded at the fat body. The lipophorin found in the mature eggs was considered by these authors to have been trapped there at the time of chorion formation.

Before explaining what we know about the interaction of hemolymph lipophorin and the ovary, the reader needs to undestand the role of lipophorin during flight. In both adult $M$. sexta and Locusta migratoria sustained flight is powered by the energy which is stored in the fat body in the form of triacylglycerol (see review by Beenakkers et al., 1985). When adult

TABLE V

Properties of lipophorins from adult Manduca sexta

\begin{tabular}{lll}
\hline $\begin{array}{l}\text { Component or } \\
\text { property }\end{array}$ & HDLp & LDLp \\
\hline Density* & $1.07^{\mathrm{b}}$ & 1.030 \\
Molecular weight ** & $7.7 \times 10^{5}$ & $15.6 \times 10^{5}$ \\
Composition * & \multicolumn{2}{c}{ Percent by weight } \\
\multicolumn{1}{c}{ Phospholipid } & 14.0 & 7.1 \\
Diacylglycerol & 25.0 & 46.9 \\
Hydrocarbon & 3.5 & 2.3 \\
Sterol & 1.3 & 0.7 \\
Triacylglycerol & 2.5 & 1.7 \\
Free fatty acid & 5.2 & 3.5 \\
Protein & 48.5 & 37.8 \\
Apoproteins* & 1 ApoLp-I & 1 ApoLp-I \\
& 1 ApoLp-II & 1 ApoLp-II \\
& 2 ApoLp-III & 16 ApoLp-III \\
\hline
\end{tabular}

* Ryan et al., 1986.

**Wells et al., 1987.
$M$. sexta prepares for flight, a neutral nonapeptide hormone, adipokinetic hormone (AKH) (Ziegler et al., 1985) is secreted from the corpus cardiacum. AKH stimulatates the mo. bilization of triacylglycerol stores in the fat body and its conversion to diacylglycerol. The diacylglycerol is then loaded onto lipophorin which transports it through the aqueous environment of the hemolymph to the flight muscle cells.

In resting adult $M$. sexta, $80 \%$ of the total hemolymph lipophorin is a high density lipophorin (HDLp) (Wells et al., 1987) that consists of $52 \%$ lipid and $48 \%$ protein (Ryan et al., 1986). It has three apoproteins: apoLp-I $\left(M_{r} \approx 250,000\right)$, apoLp-II $\left(M_{r} \approx 80,000\right)$ and apoLp-III $\left(\mathrm{M}_{\mathrm{r}} \approx 18,000\right)$ in a ratio of $1: 1: 2$ (Kawooya et al., 1984). The remaining 20\% of the total hemolymph lipophorin is the low density lipophorin (LDLp) which contains $62 \%$ lipid and 38\% protein (Ryan et al., 1986). The apoproteins of this particle exist in a stoichiometric ratio of 1:1:16 (Wells et al., 1987). When $\mathrm{AKH}$ is injected into the hemolymph of a resting animal, most of the HDLp is converted to LDLp (Shapiro \& Law, 1983). During this process large amounts of diacylglycerol from the fat body and 14 molecules of the free apoLp-III from the hemolymph, associate with the LDLp particle. When LDLp reaches the flight muscle, diacylglycerol is unloaded from the particle to the muscle cells. The oxidation of diacylglycerol in the muscle cells generates the energy that is required for the insect to maintain sustained flight. During diacylglycerol unloading, the 14 apoLp-III molecules dissociate from LDLp, and the particle decreases in size to form HDLp. By repetition of this cycle, lipophorin serves as a reutilizable shuttle for transporting lipid from the storage depot in the fat body to the flight muscle. Fig. 2 summarizes these events in a schematic fashion.

The eggs of $M$. sexta contain a lipid-depleted very high density form of lipophorin (VHDLp) that is derived from hemolymph HDLp. We have shown that HDLp is internalized by follicles both in vivo and in vitro. When HDLp enters the follicles, it undergoes transformations that include the stripping of lipid (mostly diacylglycerol) and apoLp-III from the particle. The apoproteins of the particle are not hydrolyzed during this transformation. HDLp contributes only a small fraction to the lipid stores in the egg (J. K. Kawooya, E. O. Osir 


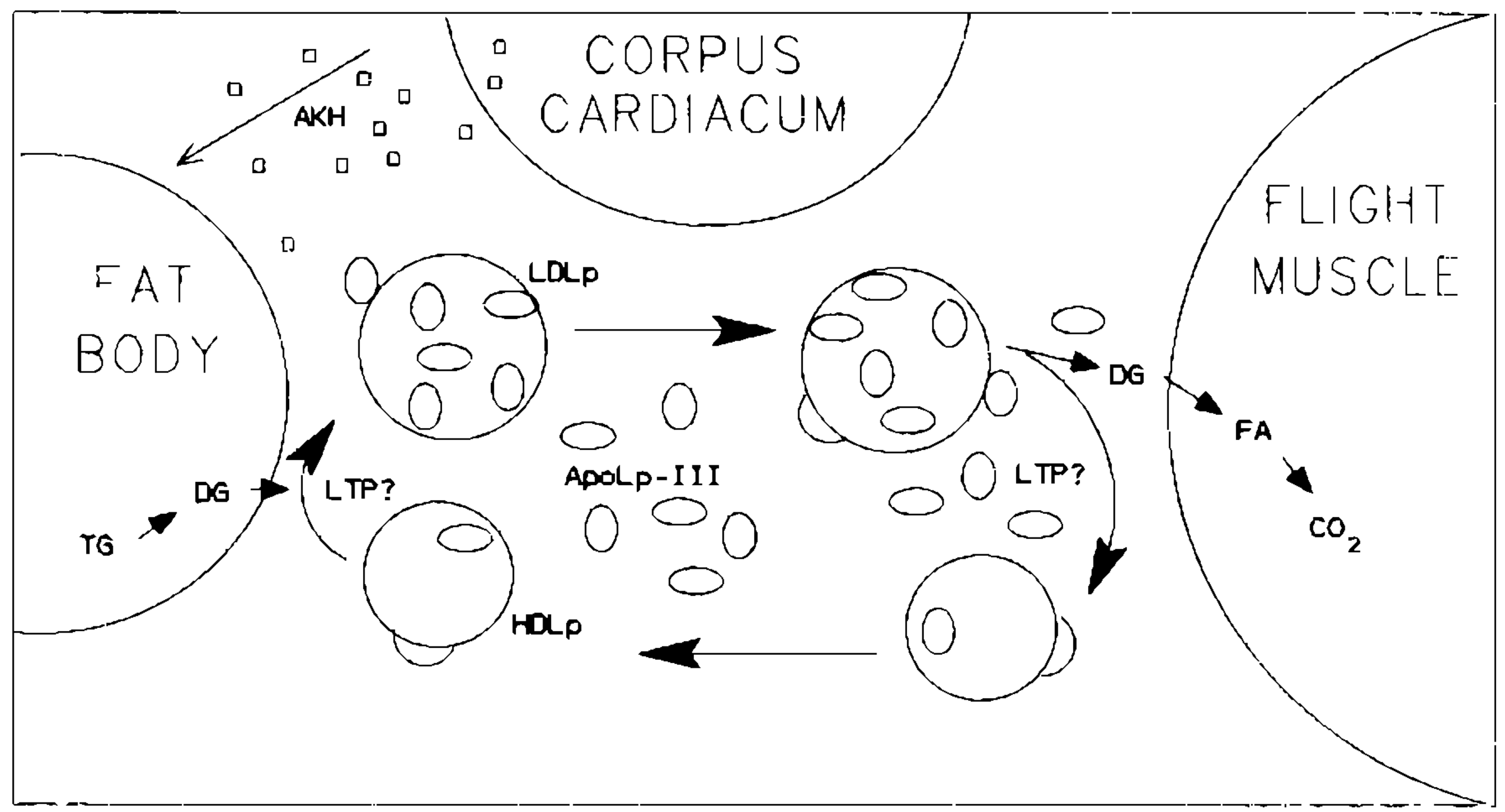

Fig. 2: Scheme depicting events stimulated by AKH in Manduca sexta.

\& J. H. Law, unpublished). Most of the lipid is delivered to the egg by LDLp. In this case, the lipid is taken from LDLp into the egg without endocytosis of the apoprotein moieties of LDLp. Thus in the egg, two different forms of lipophorin are treated differently. In one case, LDLp shuttles fat to the egg for storage, and in the other, HDLp is internalized and stored in the egg for unknown purposes (J. K. Kawooya \& J. H. Law, unpublished). This differential treatment of the two lipophorin particles suggests that each one is recognized by some form of distinct receptor system in the follicle membrane. For example, different membrane proteins might be involved. One protein may be specific for docking and unloading LDLp, and another protein may be specialized for binding and internalizing HDLp. It appears that the small amount of LDLp present in resting animals is sufficient to deliver the lipids that are required for complete vitellogenesis. It is not yet known whether AKH is required to produce that small amount of LDLp and thus if AKH plays a role in vitellogenesis.

Insecticyanin - Insecticyanin is a blue biliprotein that is made in the epidermal cells (Riddiford, 1982; Kiely \& Riddiford, 1985) and is found in the hemolymph and eggs of $M$. sexta (Cherbas, 1973) (Fig. 1). Both the primary and quaternary structure of this protein are known (Riley et al., 1984; Holden et al., 1987).

Since it appears that insecticyanin provides the blue component of the green camouflage coloration of $M$. sexta larvae and eggs (Kawooya et al., 1985), this protein must be carefully metered into the egg to produce a suitable tint. Nothing is known about the uptake of insecticyanin into the ovary, but presumably it also involves an endocytotic receptor.

Summary and Prospect - In M. sexta, vitellogenesis involves the assembly in the oocyte of several proteins and lipids that originate in the fat body in addition to materials that are synthesized by follicle and nurse cells and added to the egg in situ. Sequestration of these materials appears to involve both very active endocytosis and shuttle processes. Several of the proteins that are sequestered by the oocyte have now been well characterized. The next phase will focus on the isolation and examination of receptor and docking proteins that may be involved in the sequestration processes. Those studies will most likely involve the techniques of molecular biology, which will reveal not only the structures of the membrane proteins, but will also yield the tools necessary for studying the control of the synthesis of these proteins.

\section{REFERENCES}

BEENAKKERS, A.M.Th.; VAN DER HORST, D.J. \& VAN MARREWIJK, W.J.A., 1985. Insect lipids and lipoproteins, and their role in physiological processes. Prog. Lipid. Res., 24 :19-67.

CHERBAS, P.T., 1973. Biochemical studies of insec. ticyanin. PhD thesis, Harvard University, Cambridge.

CHINO, H.; DOWNER, R.G.H. \& TAKAHASHI, K., 1977. The role of diacylglycerol-carrying lipoprotein $I$ in lipid transport during insect vitellogenesis. Biochim. Biophys. Acta, 487 :508-516.

CHINO, H.; DOWNER, R.G.H.; WYATT, G.R. \& GILBERT, L.I., 1981. Lipophorins, a major class of lipoproteins of insect haemolymph. Insect Biochem., $11: 491$. 
DFLLA-CIOPPA, G. \& ENGELMANN, F., 1987. The vitellogenin of Leucophaea maderae. Synthesis of a large phosphorylated precursor. Insect Biochem., $3: 401-415$.

HAGFDORN, H.H., 1985. The role of ecdysteroids in reproduction. Vol. 8, p. 205-262. In G.A. Kerkut \& L.I. Gilbert. Comprehensive Insect Physiology, Biochemistry and Pharmacology. Pergamon Press, New York.

HARNISH, D.G. \& WHITF, B.N., 1982. Insect vitellins: identification, purification, and characterization from eight orders. J. Exp. Zool., $220: 1-10$.

HARNISH, D.G.: WYATT, G.R. \& WHITE, B.N., 1982. Insect vitellins-identification of primary products of translation. J. Exp. Zool., $220: 11-19$.

HOLDEN, H.M.; RYPNIFWSKI, W.R.; LAW, J. H. \& RAYMENT, I., 1987. The molecular structure of insecticyanin from the tobacco hornworm Manduca sexta L. at 2.6 A resolution. EMBO J., $6: 1565$ 1570.

IMBODEN, H. \& LAW, J.H., 1983. Heterogeneity of vitellins and vitellogenins of the tobacco hornworm. Maduca sexta L. Time course of vitellogenin appearance in the haemolymph of the adult female. Insect Biochem., $13: 151-162$.

KAWOOYA, J.K.; KEIM, P.S.; LAW, J.H.; RILEY, C.T.; RYAN, R.O. \& SHAPIRO, J.P., 1985. Why are green caterpillars green? p. 511-521. In P. A. Hedin. Bioregulators for Pest Control, American Chemical Society, Washington.

KAWOOYA, J.K.; KEIM, P.S ; RYAN, R.O.; SHAPIRO, J.P.; SAMARAWEERA, P. \& LAW, J.H. 1984: Insect apolipophorin. IIl Purification and properties. J. Biol. Chem., $259: 10733-10737$.

KAWOOYA, J.K. \& LAW, J.H., 1983. Purification and properties of microvitellogenin of Manduce sexta. Role of juvenile hormone in appearance and uptake. Biochem. Biophus. Res. Commun., $I 77: 643-650$.

KAWOOYA, J.K.; OSIR, E.O. \& LAW, J.H., 1986. Physical and chemical properties of microvitellogenin. J. Biol. Chem., 261 :10844-10849.

KAWOOYA, J.K.; OSIR E.O. \& LAW, J.H., 1988. Uptake of the major hemolymph and its transformation in the insect egg. $J$. Biol. Chem. (in press).

KIELY, M.L. \& RIDDIFORD, L.M., 1985. Temporal programming of epidermal cell protein synthesis during the larval-pupal transformation of Manduca sexta. Roux's Arch. Dev. Biol., 194 :325-335.

KOEPPE, J.K.; FUCHS, M.; CHEN, T.T.; HUNT, L. -M.; KOVALICK, G.E. \& BRIERS, T. 1985. The role of juvenile hormone in reproduction. Vol. 8 , p. 165-203. In G.A. Kerkut \& L.I. Gilbert. Comprehensile Insect Physiology, Biochemistry anci Pharmacology. Pergamon Press, New York.

KUNKEL, J.G. \& NORDIN, J.H., 1985. Yolk proteins. Vol. 1, p. 83-111. In G.A. Kerkut \& L.1. Gilbert, Comprehensive Insect Physiology, Biochemistry and Pharmacology. Pergamon Press, New York.

MUNDALL, E.C. \& I.AW, J.H., 1979. Physical and chemical charactcrization of vitellogenin from the hemolymph of the tobacco hornworm, Manduca sexta. Comp. Biochem. Physiol., 63B :459. 468.

NlJHOUT, M.M. \& RIDDIFORD, L.M., 1974. The control of egg maturation by juvenile hormone in the tobacco hornworm moth. Manduca sexta. Biol. Bull, 146 :377-392.

NIJHOUT, M.M \& RIDDIFORD, L.M., 1979. Juvenile hormone and ovarian growth in Manduca sexta. Intern. J. Invert. Reprod., $1: 209-219$

OSIR, E.O.; ANDERSON, D.R.; GRIMES, W.J. \& LAW, J.H., 1986a. Studies on the carbohydrate moicty of vitellogenin from the tobacco hornworm. Manduca sexta. Insect Biochem., $16: 471$ 478.

OSIR, E.O. \& LAW, J.H., 1986. Studies on binding and uptake of vitellogenin by follicles of the tobacco hornworm, Manduca sexta. Arch. Insect Biochem. Physiol., 3 :513-528.

OSIR, E.O.; WELLS, M.A. \& LAW, J.H., 1986 b. Studies on vitellogenin from the tobacco homworm, Manduca sexta. Arch Insect Biochem. Physiol., $3: 217-233$.

RIDDIFORD, L.M., 1982. Changes in translatable mRNAs during the larval-pupal transformation of the tobacco hornworm. Dev. Biol., $92: 330-342$.

RILEY, C.T.; BARBEAU, B.K.; KEIM, P.S.; KEZZDY, F.J.; HEINRIKSON, R.L. \& LAW, J.H., 1984. The covalent protein structure of insecticyanin, a blue biliprotein from the hemolymph of the tobacco hornworm, Manduca sexta L. J. Biol. Chem., 259 :13159-13165.

RYAN, R.O., PRASAD, S.V.; HENRIKSON, I.J.; WELLS, M.A. \& LAW, J.H., 1986. Lipoprotein interconversions in an insect, Manduca sexia. Evidence for a lipid transfer factor in the hemolymph. J. Biol. Chem., $261: 563-568$.

THL.FER, W.H. \& KUL.AKOSKY, P.C., 1984. Isolated hemolymph proteins as probes of endocy totic yolk formation. p. 81-86. In W. kngels, W.H. Clark, A. Fischer, P.J.W. Olive \& D.F. Went, Advances/in Invertebrate Reproduction 3. Hisevier, New York.

TELFER, W.H.; RUBENSTEIN, E. \& PAN, M. -L. 1981 . How the ovary makes yolk in Hyalophora. p. 637-653. In F. Senhal,-A. Zabza. J.I. Menn \& B. Cymboroski, Regulation of Insect Development and Behavior. Wroclaw Technical University Press, Wroclaw.

WELLS, M.A.; RYAN, R.O.; KAWOOYA, J.K, \& LAW. J.H., 1987. The role of apolipohorin III in in vivo lipoprotein interconversions in adult Manduca sexta. J. Biol. Chem., $262: 4172-4176$.

WYATT, G.R; LOCKE;, J. \& BRADFIELD, J.Y., 1984. The vitellogenin genes of Locusta migratoria and other insects. p. 73-80. In W. Lingels, W.H. Clark, A. Fischer, P.J.W. Olive \& D.F. Went, Advances in Invertebrate Reproduction 3. Fisevier. New York.

ZIEGLER, R.; ICKART, K, SCHWARZ, H. \& KHLLER, R., 1985. Amino acid sequence of Mandura sexia adipokinetic hormone clucidated by com. bined fast atom bombardment (F:AB)/tandem mass spectrometry. Biochem. Biophys. Res. Commun. $133: 337-342$. 